\title{
SIGNIFICANCE OF EOSINOPHILS IN DIAGNOSIS OF MICROFILARIA AMONG RURAL POPULATION OF NORTH INDIA Seema Dayal ${ }^{1}$
}

${ }^{1}$ Seema Dayal, Department of Pathology, UPUMS Saifai Etawah ( U.P) India

*Correspondence to: Dr Seema Dayal, Department of Pathology, UPUMS, Saifai, Etawah (U.P), India. Email:seema.dayal5@gmail.com

\begin{abstract}
Micro filarial infection is a common infection in India. In most of the cases microfilaria is an incidental finding in FNA smears prepared from swellings from various locations in the body Eosinophilia is generally associated with filarial infection. This study was conducted to know the association of microfilaria infection with different age group, clinical characters, eosinophilia. Method and Material: This study was done in Department of Pathology in Rural institute of Medical Sciences \& Research Saifai Etawah (U.P.), India. Here, we include 30 cases which was clinically suspicious for microfilaria and also involves others in which microfilaria was incidental finding. Usually peripheral blood examination, FNAC and biopsy are done for the diagnosis of microfilaria. Result: The age of patients was from 16 years to 80 years. Maximum number of patients was of $21-30$ years (33.33\%). Swelling was chief clinical complaint (66.66\%). Raised leucocyte count (70\%), eosinophilia (33.33\%) on blood smears, eosinophilia on cytology smears $(26.66 \%)$ and raised erythrocyte sedimentation rate (46.66 \%) were seen. Conclusion: Microfilaria infection is common health problem. Careful screening for microfilaria should be done in symptomatic and asymptomatic patients. Eosinophila is though usually seen with microfilaria infection but it is not mandatory to always found eosinophilia with microfilaria infection.
\end{abstract}

Key words: Eosinophil, ESR, Leucocyte, Microfilaria.

\section{INTRODUCTION}

Filarial infection is endemic in Latin America, Sub Saharan Africa and Southeast Asia. It is present in India as endemic, specially its infection is seen in coastal areas of India. In India, next to malaria filariasis is a major problem among mosquito borne disease. Currently, worldwide there are approximately 120 million cases of lymphatic filariasis. Filariasis is caused by mosquitoes and is caused by two closely related nematodes Wuchereria bancrofti and Brugia malayi. ${ }^{1}$ In India, the most common form of disease is caused by Wuchereria bancrofti also known as Bancroftian filariasis accounting for $9 \%$ of the cases. ${ }^{2}$ This form of filariasis is distributed in urban and rural population. It spreads in humans through mosquito bites. Though it is common infection in India, but is uncommon to diagnose microfilaria in body fluids and extremely rare in subcutaneous swelling. The diagnosis of microfilaria is done by visualization of microfilaria under microscope. Raised Eosinophil count is associated with microfilaria infection. This study was conducted with aim to analyze association of microfilaria infection with different age group, their clinical symptoms and haematological parameters specially eosinophilia.

\section{MATERIAL AND METHOD}

The study was conducted in the Department of Pathology from December 2014-December 2015 at Rural Institute of Medical Sciences \& Research Centre, Saifai, Etawah (UP), India.

30 cases were included in present study. All these patients were thoroughly examined and routinely investigated. All relevant details were included in study. Aspiration were obtained by 22-23 gauge needle attached with disposable syringe, associated investigation such as total, differential leucocyte 
count and ESR was done in each case. For FNAC, smears were wet fixed immediately in $95 \%$ alcohol and stained by haematoxylin and eosin stain. Air dried smears were stained by May-Grunwald Giemsa stain . For hematology, Leishman's stain was applied and results were also compared with cell counter reports.

\section{RESULT}

The most common age range at presentation was 21-
30 years $(33.33 \%)$, with a range from $17-80$ years. The disease was more prevalent in males and females ( $M$ : $\mathrm{F}=1.5: 1)$. In the present study, most cases presented with swelling $(66.66 \%)$. The size of swelling ranged from $1 \mathrm{~cm}$ to $6 \mathrm{~cm}$. Other clinical complaints were pain (40\%), fever (26.66\%) and miscellaneous such as urticaria (16.66\%). Hematological investigations such as TLC, DLC, ESR was also done. Leucocytosis was seen in (70\%), Eosinophilia $(33.33 \%)$ on blood smear, Eosinophilia (26.66\%) on cytology smear and raised ESR was seen in (46.66\%).

Table 1: Table showing age of patients

\begin{tabular}{|l|l|l|l|l|l|l|l|}
\hline$\leq \mathbf{2 0}$ years & $\mathbf{2 1 - 3 0}$ years & $\mathbf{3 1 - 4 0}$ years & $\mathbf{4 1 - 5 0}$ years & $\mathbf{5 1 - 6 0}$ years & $\mathbf{6 1 - 7 0}$ years & $\mathbf{2 7 1}$ years & Total \\
\hline $2(6.66 \%)$ & $10(33.33 \%)$ & $6(20 \%)$ & $6(20 \%)$ & $4(13.33 \%)$ & $1(3.33 \%)$ & $1(3.33 \%)$ & $30(100 \%)$ \\
\hline
\end{tabular}

Table 2: Table showing clinical symptoms of patients

\begin{tabular}{|l|c|l|}
\hline Symptom & Number & Percentage \\
\hline Swelling & 20 & $(66.66 \%)$ \\
\hline Pain & 12 & $(40 \%)$ \\
\hline Fever & 8 & $(26.66 \%)$ \\
\hline Miscellaneous & 5 & $(16.66 \%)$ \\
\hline
\end{tabular}

Table 3: Table showing associated haematological investigation

\begin{tabular}{|l|c|c|c|c|c|c|c|l|}
\hline Age Investigation & $\mathbf{2 0}$ years & $\begin{array}{c}\mathbf{2 1 - 3 0} \\
\text { years }\end{array}$ & $\begin{array}{c}\mathbf{3 1 - 4 0} \\
\text { years }\end{array}$ & $\begin{array}{c}\mathbf{4 1 - 5 0} \\
\text { years }\end{array}$ & $\begin{array}{c}\mathbf{5 1 - 6 0} \\
\text { years }\end{array}$ & $\begin{array}{c}\mathbf{6 1 - 7 0} \\
\text { years }\end{array}$ & $\begin{array}{c}\mathbf{2 7 1} \\
\text { years }\end{array}$ & Total \\
\hline Leucocytosis & 1 & 7 & 4 & 5 & 2 & 1 & 1 & $\mathbf{2 1 ( 7 0 \% )}$ \\
\hline Eosinophilia on blood smear & 1 & 4 & 3 & 1 & 1 & 1 & 0 & $11(36.66 \%)$ \\
\hline Eosinophilia on FNA smear & 1 & 3 & 1 & 2 & 1 & 0 & 0 & $8(26.66 \%)$ \\
\hline Raised Erythrocyte sedimentation rate & 1 & 5 & 4 & 2 & 2 & 0 & 0 & $14(46.66 \%)$ \\
\hline & 4 & 19 & 12 & 10 & 6 & 2 & 1 & \\
\hline
\end{tabular}

Discussion: Filariasis is caused by thread like worms. Microfilarial infection is a global health problem and is endemic in India. Filaria infections are caused by Wuchereria bancrofti. An adult worm can obstruct lymphatics and cause lymphedema and fibrosis. These worms when they reside in skin than they form nodule. ${ }^{3}$ Wuchereria bancrofti causes $90 \%$ and Brugia species causes $10 \%$ of total number of infections worldwide. ${ }^{4}$ The disease caused by this parasite mainly involves lymph nodes and lymphatic system, body fluids, breast, lung and skin. ${ }^{5}$ It is a disease with poor effect on social and Economic aspects. The chronic manifestations of disease are irreversible and may cause temporary disability. In present study, male female ratio was 1.5:1 where in study done by Sarojini $S^{2}$ female were more infected with disease. In endemic areas for microfilaria infection, micro filaremia develops early in life. ${ }^{6}$ The age of infected patients was ranged from 16 to 80 years and maximum number of cases were in $21-30$ years age group (33.33\%) similarly Andola $\mathrm{S}^{7}$.

Filariasis has a wide spectrum of clinical manifestations with sign and symptoms often differing from one endemic area to other. ${ }^{8}$ The disease phases are obstruction, inflammation and allergy. Most infected people in endemic areas are asymptomatic. It may be swelling, fever, pain, lymphadenitis, funiculities, tropical 
pulmonary eosinophilia, hydrocele, chyluria.

In present study swelling was chief clinical complaint (66.66\%) followed with pain and fever similar results were also observed by Andola $\mathrm{S}^{7}$ in his study.

Hematological examination such as Total luecocyte count, Differential leucocyte count, Erythrocyte sedimentation rate are useful in the diagnosis of filarasis. As filariasis is associated with inflammatory condition so usually leucocyte count and ESR are raised. ${ }^{9,10}$ This study also justifies it because raised leucocyte count (70 \%) and raised $\operatorname{ESR}(46.66 \%)$ was found.

Eosinophils are produced in bone marrow. They measures 12- 17 um in diameter. Nuclei are usually bilobed with orange colour granules. ${ }^{11}$ Eosinophils comprises of $1-4 \%$ of white cells. Increase in eosinophil count is the presence of more than 500 eosinophils per micrlitre of blood. A wide range of disorders are responsible for an increase in eosinophils in blood as well as in many organs like lungs, CNS, skin and in organ dysfunction. Eosinophilia is observed in parasitic infestations like filariasis, round worm, hook worm infestation and echinococcosis. ${ }^{12}$ Our results also has similar results, eosinophilia on blood smear was (33.33\%) and on cytology smear was (26.66\%).

\section{CONCLUSION}

India is an endemic country for filarial infection. It causes morbidity and mortility to affected pesons. It is necessary to examine every swelling carefully keeping filariasis as diagnosis in mind because it helps clinician to reach early diagnosis of filarial infection and its treatment. Raised eosinophil count is usually associated with filarial infection, but may be raised in other numerous pathological conditions.

\section{REFERENCES}

1. Park K. In : Park's Textbook of Preventive and Social Medicine. $18^{\text {th }}$ ed. Jabalpur, India: Bhanot Publishers; 2005:211-6.

2. Sarojini S, Sentilkumar P. Haemtological studies of Iymphatic filariae, Wuchereial bancrofti affected patients in Arakkonam area, Tamil Nadu India. European journal of experimental biology 2013;3(2):194-200.
3. Pantola C, Kala S, Agarwal A, Khan L. Microfilaria in cytologicalsmears at rare sites coexisting with unusual pathology: A series of seven cases. Trop Parasitol 2012;2(1):61-63.

4. Muddamwar VG, Rane MS, Shewale SP, Sameer MA, Deshpande MS, Phasge G. Midarm lymphadenopathy - A rare presentation of filariasis in a 20 year old female in Nanded Region. International Journal of Pharmaceutical Science Invention May 2014;3(5):12-16.

5. Varghese R, Raghuveer CV, Pai MR, Bansal R. Microfilariae in cytologic smears: A report of six cases. Acta Cytol 1996;40:299-301.

6. Mitra SK, Mishra RK, Verma P. Cytological diagnosis of microfilariae in filariasis endemic areas of eastern Uttar pradesh. J Cytol 2009;26:11-4.

7. Andola S, Naik A. Microfilaria and filarial granulomas from fine needle aspirates. A study of 25 cases. Southeast Asian J Trop Med Public Health 2011;42(6):1351-1358.

8. Mitra SK, Mishra RK, Verma P. Cytological diagnosis of microfilariae in filariasis endemic areas of eastern Uttar Pradesh. J Cytol 2009;26(1):11-14.

9. Mohan H. Practical book of Pathology. $3^{\text {rd }}$ edition 2013, Jaypee publications New Delhi, India.

10. Chaturvedi U, Singh T. Practical Pathology . $2^{\text {nd }}$ edition 2007, Arya Publications, New Delhi, India.

11. Mandal AK, Choudhury S. Text book of Pathology. Ist edition 2010, Avichal publications. New Delhi, India.

12. Singh T. Text and practical Haematology. Ist edition 2010 , Arya publications New Delhi, India.

JCMC/ Vol 7/ No. 2/ Issue 20/ Apr-Jun, 2017 